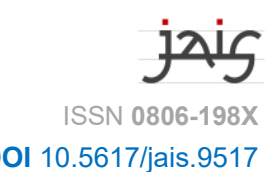

\title{
Mobile Phones
}

\author{
By ALBReCht HofHeINZ
}

Mobile phones are everywhere - or so it seems. 'Everyone' has one ( $88 \%$ of Egyptians, for example). Wherever you look, wherever there are people, you will see them talking into a handheld, gazing at a screen, swiping across a glass plate, taking a selfie, recording a video. Mobile phones are regarded as an essential tool of communication in a region where landlines have always been insufficient. Nowadays, fixed telephony is mostly a residue of the past. Everyone relies on cellphones; running out of battery power is a serious issue; and many people have more than one phone so as to be able to toggle between different providers, depending on which one their friends use. Weak cellphone reception in new housing areas is among the serious issues new residents protest at. And the news that the French-majority owned company Orange threatens to withdraw from the Tunisian market and thereby "leave 3.6 million customers offside" causes a big stir - with some arguing that «Qua[n]d on ne consomme pas tunisien on merite de se trouver en hors jeux». The brouhaha is intended by Orange, however, to put an end to five years of anti-corruption proceedings ( $51 \%$ of Orange Tunisie is controlled by a company owned by deposed president Bin 'Alī’s former son-inlaw) and to try to increase its shareholder percentage [ $\lambda$ Inferiority vs. Superiority]. Undoubtedly, mobile telephony is a big market; by the end of the year, Orange is not only growing in Tunisia, but has crowned its takeover of Egypt's Mobinil by rebranding as "Orange Egypt." Social media users mourn the demise of a brand that had endeared itself to the public with advertising campaigns echoing popular culture and patriotic attitudes.

You can change the Name but u can never wipe the history of $17 \mathrm{y}$. Mobinil name was inspired by a man who had a Dream to lead telecommunications in Egypt to the worldwide level but he want it with Egyptian spirit so he attached its name to the Nile with a wave of our sun \& greenlands, his aim to let everyone use mobilephones even the poor ppl who doesn't know how to dial a simple number, Mobinil ads were touching every Egyptian heart and keeping the bond connected, it encouraged ppl to speak from the heart $[\ldots]$ we gained alot of priceless friends \& even our spouse.

While the public waxes in nostalgia [ $\nearrow$ Past $v$ s. Present], investors and technocrats work hard to put in place the next, or "Fourth Generation" (4G) network. In Tunisia, first experimental 4G services begin in March; by autumn, 4G is well-established commercially. In Egypt, things take a little longer as state-owned Telecom Egypt (TE) wants a share in a market where hitherto only foreign companies have invested. In the summer, TE is the first to be given a $4 \mathrm{G}$ license in the country; the necessary infrastructure is to be built by the Armed Forces Engineering Authority. A few months later, regulatory agreements are in place also with the three foreign-owned companies (Etisalat, Orange, and Vodafone) that are being pressured to pay half of the value of the spectrum in US Dollars [ $\nearrow$ Dollar Crisis].

Mobile looks like a lucrative market also to the highest echelons of state. Everyone has one, the President reasons, so "if only 10 of the 90 million mobile phone owners in Egypt donated one pound for Egypt every morning, we would have LE10 million every day" in the

Journal of Arabic and Islamic Studies • 21 (2021) - Themed Section In2016: *187_*196 (C) Albrecht Hofheinz, Dept. of Culture Studies and Oriental Languages (IKOS), Univ. of Oslo, NO 
"Long Live Egypt" fund. As such admonitions do not bear fruit, a value-added tax of $22 \%$ is being imposed on consumers, prompting the creation of a Facebook campaign to urge its one million followers to refrain from recharging their prepaid cards for a couple of days ("Mish ha-nishhan") and calling their Facebook event no less than an "Internet Revolution" (Thawrat al-Internet).

Every now and then, people toy with such insubordinate ideas. "Does the mobile camera make you tremble?" (\#kāmērāa_il-mōbāyl_bit’hizzak?) asks a hashtag campaign on Twitter after Ațfāl Shawāric, the "Street Children," are arrested. This band of six young men have achieved notoriety on YouTube for a series of videos highly disrespectful of hollow hegemonic social norms and political taboos, filmed with a selfie stick in the dim light of street lamps [ $\nearrow$ Pop Music, $\nearrow$ Inferiority = Superiority (Satire), $\nearrow$ Social Media]. When the army boots they made fun of in 'Abadat il-Biyāda ("The boot worshippers") come crushing down on them, thousands of social media users post pictures of themselves behind a mobile camera, tagged with this provocative question. Such photos are taken not only in the secluded space of private homes but also in public and as a group, for example when the collective graduation picture of al-Minūfiyya University's Department of Journalism is posted in this style. "No video, no photo, no drawing will make tremble anyone but the feeble and weak," comments cartoonist Islām Ğāwīsh. A few months later, Aṭ̂āl Shawāric are quietly released, and have stayed quiet since.

That the authorities want to keep an eye on what the ubiquitous mobile media are used for is illustrated by the abrupt end of Facebook's "Free Basics" programme in Egypt - a service that provides "access to basic websites for free" on mobile phones and that had been installed by 3 million Egyptians. Insiders report that the service was stopped because Facebook "would not allow the government to circumvent the service's security to conduct surveillance." In Tunisia, the service is not available either. On the other hand, "Tunisia is among the first countries to benefit from the roll-out of Facebook's Messenger Lite," an app that "offers the core features of Messenger for markets with slower-than-average internet speeds and a prevalence of basic Android smartphones." There is a huge demand for tools that deliver mobile internet to those who are unable to afford a fancier phone. In Egypt, "Facebook for Every Phone" (which provides Facebook access for cheaper feature phones) is the second-most popular Facebook page after that of televangelist Muștafà Husnī [ $\nearrow$ In Islam, ... ]. The hunger for such personal and 'private' instruments of communication is enormous and extends far beyond those specifically interested in political matters: everyone likes a good gossip, and the WhatsApp conversations of two lovers, rendered into a 'poetry' book, arouse some attention at the Cairo book fair (though the publication fails to convince readers in the long run). Whatever the motives, however, there is a widespread, stereotype idea that 'everyone has a mobile phone and they are all using it to no good'- be that antigovernment conspiracy or simply wasting one's time on chat and distraction. "All Egyptians have bought expensive mobiles just to open Facebook" is one of the myths that a critical blogger and journalist tries to debunk; he may have a point in pointing out the harsh economic realities in a country where the GDP is only $22 \%$ of the world average [ $\lambda$ Affluence vs. Destitution], but his claim that only $22 \%$ of the population use a smartphone is likely out of date. A dedicated study puts smartphone usage in Egypt at $61 \%$ and in Tunisia at $43 \%$ (though

jais • 21 (2021) - Themed Section In2016: *187_*196 
only $31 \%$ in both countries have fixed subscriptions to mobile broadband). The younger one is and the more educated, the more likely one is to use a smartphone [ 7 Young vs. Settled].

The mobile phone is used as an instrument and regarded as a symbol for an individual's independence - and simultaneously it is a battleground for attempts at surveillance and control [ $\lambda$ Security vs. Fear]. This begins long before the state gets involved. One of " 15 Egyptian girl problems" is that "if you do not answer your phone in the first seven seconds, your mother WILL call you nonstop and then begin to call each of your friends individually, frantically searching for you. It will be awkward and embarrassing." At least, Egypt has achieved gender equality in regard to mobile phone use; in Tunisia, more men (49\%) than women (37\%) own smartphones, and on the Arabian Peninsula, the hashtag "Would you marry a girl with a mobile phone?" (هل_تتزوج_بنت_معها_جوال) is trending for a while (in Egypt, this elicits only a sarcastic response) [ 7 Male vs. Female]. After the family, the state moves in to control. In the Tunisian film Zahrat Halab, jihadis take away the phones of those coming to join the Islamic State. And on Egyptian streets, security forces routinely inspect (also here) or confiscate mobile phones for evidence of compromising, 'unlawful' attitudes, as well as to access suspects' social networks (see this whole article, with pictures of plainclothes security forces searching phones ahead of the demonstrations announced in April re the RS islands, as had happened ahead of $25 \mathrm{Jan}$; also here searching for evidence in a criminal investigation). "If you are an Egyptian and carry a smartphone, you're all but suspect of being in possession of contraband, and there is a big likelihood that the police will arrest you." Under this slightly exaggerated headline, one can find "10 tips for not getting arrested by the police when they check your phone." "Don't surf while out on the street!" "Don't use your phone in the metro!" "Erase all political conversations" and only keep a few apolitical funny videos. "Use the image of President 'Abd al-Fattāh al-Sīsī as your phone's background picture!" "Swap your smartphone for an old one!," but best, "Leave your mobile at home!" The risks are real; the Egyptian Coordination for Rights and Freedoms (ECRF) launches an "I Protect" app for Android "through which [users] can send an SOS message with their location to up to three people and to the ECRF in case they are arrested and face potential forced disappearance" [ $\nearrow$ Disappearances]. The app struggles, however, with technical problems and is not being further developed. Meanwhile, the state imports advanced, British-made telecommunication surveillance equipment "to intercept private phone messages and hack into devices"- apart from resorting to low-tech traps to frame people, such as when the "morality police" messages an obscure actress and sets up a 300 USD/hour date with her so as to arrest her for prostitution (the actress claimed she had "only been joking." Real sex workers use separate phones for their red-light activities in an attempt to protect their privacy, if not from the state so from their families and their ordinary social networks. But phones are not only used to arrange 'illicit' sexual encounters; many a homemade porn video - "typically captured on low-quality cellphone or laptop cameras that are often hidden from view of the women being filmed" ends up on the internet, often "leaked by third parties, such as computer repair shops that accidentally find this content in their customers' devices," or are being shared from phone to phone via Bluetooth. Occasionally, such leaks create a scandal. Usually, the victim is then blamed for immoral behaviour, but in a highly mediatized case, a lower court in Giza sentences a prominent TV host (Rihām Sa ${ }^{c} \overline{1} \mathrm{~d}$ ) to prison and a fine for "violating [an individual's] personal freedom" (al-ictida $\vec{a}^{\prime}$ 'alà 'l-

jais • 21 (2021) - Themed Section In2016: *187-*196 
hurriyya al-shakhsiyya) by airing highly private photographs stolen from the phone of the so-called "mall girl" (a woman who had been harassed in a shopping mall) to suggest that "her personal choices warranted the assault" (Rihām wins the case on appeal) [ $\nearrow$ Court Trials].

Much beyond such scandals, however, the 'privacy' gain made possible by cellphones hugely facilitates, for millions of individuals, their setting up meetings and navigating physical and social labyrinths, avoiding traffic jams or the prying eyes of neighbours. As much as they can be turned into instruments of control, mobile phones are also used as a means of affirming one's auto-determination. This may manifest itself as obstinate withdrawal; in Clash, a young man turns to his cellphone to cushion himself from the crazy crowds around, by listening to mahragānāt music [ $\nearrow$ Pop Music]. Or it may result in new forms of enterprise that challenge established ways of doing things by exploiting the affordances of the new mobile technology. A few men with green concerns launch the app 'Environ Reform' that allows people to send pictures of garbage accumulating in the street directly to the local waste management company as well as to an NGO monitoring the situation [ $\lambda$ Garbage]. Ride-hailing apps Uber and Careem take the Egyptian market by storm [ $\lambda$ Uber]. "Big dreamer" Aḥmad Zakī develops Rakna, "the Uber of parking." If you do not have a car but do not want to risk "rubbing against random sweaty strangers" on public transportation lines, you can turn to Buseet to book your ride on a minibus sharing site. Yumamia, "the Uber of food," "turns Egyptian housewives into entrepreneurs"; it promises "junk-free \& clean food delivered in 60 minutes" to any residential area in Cairo and wins "the prestigious Publicis90 Global Startup Competition silver award, out of 3,500 other digital startups from 141 countries worldwide." The concept is so successful that it allows for similar food-delivery startups to flourish, such as Mumm, or Zayt Zaytūn/Zeit Zatoun, a kitchen run by Syrian refugees [ $\nearrow$ Migration]. Kids in primary and intermediate school can be provided with the Ketapedia app that offers the official curriculum in an immersive, gamelike experience. And everybody can become a pollster using Nis'alak/Nes2alak, an app developed by the Egyptian Centre for Public Opinion Research-Bașīra/Baseera.

Perhaps it is precisely in reaction to such new social phenomena, to innovative ways of behaving in society and politics, that stereotype images are so frequently repeated of young people not conforming to the traditional demands of society, but getting dragged down by these technologies into becoming superficial, useless kids ('ayyil täfih). Many a young person, this cliché holds, is "only interested in his clothes, his car, his type of mobile"; lazy boys wasting time playing games on their mobiles, they are contrasted with the few who sacrifice themselves to provide for their families. Gaming is certainly popular; $59 \%$ of smartphone users in the Arab world play games on their phones, including $45 \%$ of young children up to six years of age. Three quarters of that time are spent gaming alone. "Tunisians are the most likely to play games on a phone every day"; Tunisians who do so spend an average 8 hours a week playing games; Egyptians 5 hours. Men are slightly more avid gamers than women, but only slightly so. Gaming decreases with age but increases with education. The Pokémon Go craze hits Egypt just like the rest of the world even before the game is officially released there - and both government and religious authorities immediately express concern over its detrimental effects (in Tunisia, the game is not officially made available). "Will people neglect $[\ldots]$ earning their living and devote themselves instead to hunting for 
Pokemon?" wonders the Deputy of Shaykh al-Azhar. And the former president of the National Research Centre believes the game "could be used for espionage and information gathering." Consequently, a cabinet spokesman announces that "all apps downloaded on smartphones will be probed and scrutinized [...] to find out if they pose a threat to the country's national security."

In all these dimensions, a tension is noticeable between the wish to embrace the opportunities offered by mobile telephony, and the fear that too much uncontrolled individualized communication poses a threat to the dominant social and political order [ $\lambda$ Security vs. Fear]. The fact that the ubiquity of mobile phone cameras means that basically everything can and is being filmed and publicly exposed vexes authorities and guardians of morality. Technological and social efforts to police mobile phone usage, in addition to physical threats and clampdowns, have a certain effect, primarily in the political realm; there are no big leaks of human rights' abuses caught on camera phones. The mobileenabled exposure of the private on public channels, however, attracts the crowds; a girl like Shurūq 'Abd al-'Azīz achieves notoriety for her selfie videos filmed inside her home, her bedroom, her car, or the gym, teasing the viewer with her well-shaped body, displaying female fashion, and presenting, in a girlish manner, satirical comments on various social matters. Such social and moral transgression comes in handy when the authorities want to strike at open criticism. Following the 'condom incident' [ $\lambda$ Inferiority = Superiority (Satire), $\lambda$ Downtown/Centre-ville, $\lambda$ Commemoration / Memorial Days], Shurūq in one of her videos publicly shames the police for its transgressions:

Raping a mentally handicapped girl in a police station is no cause for shame. Killing a doctor $[\ldots]$, a child $[\ldots]$, a young man $[\ldots]$ a demonstrator, in cold blood, is no cause for shame. [...] 40000 political prisoners [...], jailing journalists, arresting activists, even children, all that is no cause for shame. A clinically dead political life [...], no breathing space for the youth, a terrifying security grip, no accountability for killing, all that is no cause for shame. But when two young guys make a mocking video as an outlet for their concern - that is regarded by Sisi's state as a cause for shame.

A police officer responds with a selfie video containing a polite but stern warning to the "wannabe celebrity." Eight months later, Shurūq is arrested and sentenced to a year in $\lambda$ Prison for alleged prostitution; the police are open about having set her a trap on the social proximity networking app WhosHere [ $\lambda$ Celebrities, $\lambda K a m \bar{\imath} n, \lambda T h e$ Policeman Criminal, 入Social Media].

Shurūq's videos are but the tip of a wider social phenomenon-the popularity of taking selfies. People take selfies with stars, and stars take selfies with their fans (Egyptian soft pop king Tāmir Husnī while touring Tunisia; beach volleyball player $\operatorname{Du}^{c} \bar{a}^{c}$ al-Ghubāshī after representing Egypt for the first time at an Olympic tournament, wearing a hijab). People take selfies with officers at the empty Tahrīr Square on 25 January and at the army booth at the Cairo International Book Fair. People take selfies with Sisi himself. Lawmakers take selfies during the opening ceremony of parliament (and are being denounced for disrespect). A Tunisian soldier takes a smiling selfie next to a dead terrorist (and is praised by the Minister of Defence). An app developed to promote the film Clash allows you to place your selfie behind the bars of a police van. An Egyptian professional photographer pursues a project

jais • 21 (2021) - Themed Section In2016: *187-*196 
where he takes selfies on Egypt's highest or otherwise highly iconic spots [ $\neg$ Beautiful vs. Ugly]. People post selfies to support—or to make fun of — a Facebook campaign encouraging public transportation. In this omnipresent possibility of self-taken images, however, there always lurks the danger of disturbing public order and morality. Ațāal Shawāric are not the only ones facing punitive measures for such offences. The puppet Abla Fāhìtā is taken to court and charged with defying "the values and ethics of Egypt" after presenting sexy selfies in red lingerie and reading Fifty Shades of Grey on her hugely popular TV and YouTube show [ $\lambda$ Court Trials, $\lambda$ Inferiority $=$ Superiority (Satire)].

The popularity of selfies provides perhaps the most striking illustration of how people use the mobile phone as a tool for the expression and public presentation of 'myself'. This 'self' is always socially embedded, but in it lies a momentum of insubordination and unruliness

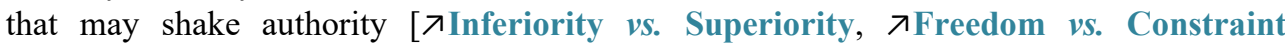
(Individual vs. Collective)]. The selfie spread on social media and hashtagged \#Does_the_mobile_camera_make_you_tremble" aptly sums up this dynamic.

\section{Related Entries}

ARRAYS - Celebrities $\downarrow$ Commemoration $/$ Memorial Days $\downarrow$ Court Trials $\downarrow$ Disappearances $\downarrow$ Dollar Crisis $\diamond$ Downtown/Centre-ville $\diamond$ Garbage $\diamond$ In Islam, ... Kamin $\diamond$ Migration $\diamond$ Pop Music $\diamond$ The Policeman Criminal $\diamond$ Prison $\diamond$ Social Media $\downarrow$ Uber

CODEs - Affluence $v s$. Destitution $\downarrow$ Beautiful vs. Ugly $\diamond$ Freedom vs. Constraint $\downarrow$ Inferiority $v s$. Superiority Male vs. Female Past vs. Present $\downarrow$ Security vs. Fear Young vs. Settled

CODES COLLAPSED - Inferiority $=$ Superiority (Satire)

\section{References}

\section{Written}

"15 Egyptian Girl Problems You Can Probably Relate to." CairoScene, April 2, 2016, <http:// www.cairoscene.com/LifeStyle/15-Egyptian-Girl-Problems-You-Can-Probably-Relate-To>.

"16 of 2016: The Egyptian Men and Women Changing the Country." CairoScene, December 30, 2016, $<$ http://www.cairoscene.com/LifeStyle/16-of-2016-Egypt-s-Real-Influencers>.

ABŪ 'L-GHAYṬ, Muḥammad. "Yā muğtama' al-15\% nuqaddim lakum: Mișr." al-Maṣrī al-Yōm, September 28, 2016, <http://ww.almasryalyoum.com/news/details/1016135>.

AButAleb, Yasmeen, and Joseph MenN. "Exclusive: Egypt Blocked Facebook Internet Service over Surveillance - Sources." Reuters, April 1, 2016, <https://www.reuters.com/article/us-facebookegypt/exclusive-egypt-blocked-facebook-internet-service-over-surveillance-sourcesidUSKCNOWY3JZ>.

AHMAD Muğāhid. "Qișșat muhağğaba așbaḥat ḥadīth al-āalam: shağğacathā al-sifāra al-almāniyya wașaffaqa lahā ğumhūr İțāliyā." al-Mașrī al-Yōm Lāyt, August 10, 2016, <http://lite.almasryalyoum. org/extra/106335>.

AḤMAD Șalāh al-Dīn. "Min ḥafl takharruğ Ādāb al-Minūfiyya Qism I'lām.” Twitter, May 23, 2016 , $<$ https://twitter.com/CheSalahElDin/status/734714638533861377>.

AḤMAD Salāma. "Ḥabs al-mumaththila Shurūq 'Abd al-'Azīz bi-tuhmat al-taḥrị̣ 'alà al-fuğūr." Veto, September 22, 2016, <http://www.vetogate.com/2421882>. 
'AnĀNĪ, Mayy, and Amānī al-AKhras. "Ǧanḥ al-Ǧīza taqụī bi-ḥabs Rīhām Sacīd 18 shahran wagharāmat 10 ālāf ğunayh bi-qaḍiyat fatāt al-mōl." al-Yawm al-Sābic, February 22, 2016,

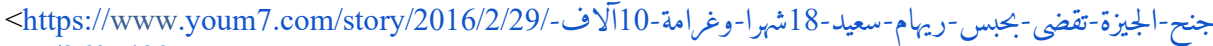
/2607489>.

ASHRAF 'Abd al-Ḥamīd. "Șūratān li-fatātayn tahuzzān mawāqi' al-tawāṣul al-iğtimācī fì Mișr." al'Arabiyya, November 7, 2016, >https://www.alarabiya.net/ar/last-page/2016/11/07/-صورتان-لفتاثين

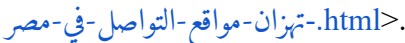

BARTON, James. "Facebook Deploying Messenger Lite in Kenya, Malaysia, Sri Lanka, Tunisia and Venezuela." Developing Telecoms, October 4, 2016, <https://www.developingtelecoms.com/tech/ apps-content-ott/6743-facebook-deploying-messenger-lite-in-kenya-malaysia-sri-lanka-tunisiaand-venezuela.html>.

BAȘīRA—al-Markaz al-Miṣrī li-Buḥūth al-Ra'y al-'Āmm, <http://www.baseera.com.eg>, accessed April 13, 2018.

BAwWĀBAT Tūnis - Tunigate. “'Ājil: 'Orange' tuhaddid bi-mughādarat Tūnis wa-tark akthar min 3 malāyīn min hurafāihā fī al-tasallul...." Facebook, October 20, 2016, <https://fb.com/Tunigate/ posts/1779568852295030>.

BoraIE, Eihab. "The Environmental App that Could Actually Clean Up Egypt." CairoScene, October 10, 2016, <http://www.cairoscene.com/Buzz/The-Environmental-App-That-Could-Actually-Clean-UpEgypt>.

"Buseet: Public Transportation à la Carte." CairoScene, September 20, 2016, <http://www.cairoscene. $\mathrm{com} /$ Travel/Buseet-Public-Transportation-A-La-Carte>.

Charbel, Jano. "Taxi Drivers Protest against Uber, Other App-based Car Services." Madà, February 4, 2016, <https://www.madamasr.com/en/2016/02/04/feature/politics/taxi-drivers-protest-againstuber-other-app-based-car-services>.

ChiтI, Elena. "The Egyptian Army, Always There since the Pharaohs (Photo Feb 6th)." Evernote, February $6,2016,<$ https://www.evernote.com/shard/s612/sh/c8434974-7ebe-49d7-94b0-75b7e90e6ea7/ cf347800a9eccff1\#>.

Dennis, Everette E., Justin D. Martin, and Robb Wood, with Marium SAEED. "Media Use in the Middle East, 2016: A Six-Nation Survey." Northwestern University in Qatar \& Doha Film Institute, n.d., $<$ http://www.mideastmedia.org/survey/2016/uploads/file/NUQ_Media_Use_2016_Final_Full_Demo. $\operatorname{pdf}>$.

DRUGEON, Antony. "La 4G arrive en Tunisie: à quels changements s'attendre?" HuffPost MG, March 10, 2016, <https://www.huffpostmaghreb.com/2016/03/10/4g-tunisie-changements_n_9425008. html>.

“EGYPT GDP per Capita 1960-2018." Trading Economics, <https://tradingeconomics.com/egypt/gdpper-capita>, accessed April 12, 2018.

"Egyptian officials say 'Pokémon Go' jeopardizes country's national security.” Al Arabiya Net, July 14, 2016, <http://english.alarabiya.net/en/variety/2016/07/14/Egyptian-officials-say-Pok-mon-Gojeopardizes-country-s-national-security-.html>.

“EGyPT’s Activists Turn to Social Media to Call for Satirists' Release.” The Guardian, May 12, 2016, $<$ https://www.theguardian.com/world/2016/may/12/egypts-activists-social-media-facebooksatirists-release-awlad-el-shawarea>.

"FADīḤT Shurūq 'Abd al-'Azīz tasubb al-shurța bi-alfāz khārija wa-radd zāait shurța 'alà ihānatihā." Kōmīdiyā Brōdkashn YouTube Channel, October 21, 2016, <https://youtu.be/S0XGwfgi2pY>.

"FACEBOOK Stats for Fans in Egypt." Socialbakers, <https://www.socialbakers.com/statistics/facebook/ pages/local/egypt>, accessed August 8, 2016.

"Food Startup Yumamia Wins Silver Award at Publicis90." CairoScene, July 14, 2016, <http://www.cairoscene.com/Eats/Food-Startup-Yumamia-Wins-Silver-Award-at-Publicis9>.

jais • 21 (2021) - Themed Section In2016: *187_*196 
FRENKEL, Sheera, and Maged ATEF. "Facebook's Big Idea for the Internet is Stalling in Egypt." BuzzFeedNews, January 20, 2016, <https://www.buzzfeed.com/sheerafrenkel/facebook-tried-togive-everyone-in-egypt-the-internet-it-did?utm_term=.jyw8a8ajP\#.yuLXEXERW>.

GRIFFIN, Andrew. "Government Has Been Allowing UK Firms to Sell Invasive Spying Equipment to Countries Including Saudi Arabia, Records Show.” Independent, January 27, 2016, $<$ https://www.independent.co.uk/life-style/gadgets-and-tech/news/government-has-been-allowinguk-firms-to-sell-invasive-spying-equipment-to-countries-including-saudi-a6836651.html>.

HaLAwA, Ibrahim. "App Launches in Egypt to Combat Forced Disappearances." The Guardian, September 6, 2016, <http:/www.theguardian.com/world/2016/sep/06/app-launches-egypt-combatforced-disappearances-i-protect>.

"Human Rights in Tunisia a Work in Progress." Fanack, March 12, 2018, <https://fanack. com/ tunisia/human-rights/human-rights-a-work-in-progress $>$.

ḤuSĀM al-Sukkarī. "Anā khā̄if min hādhā al-wațan... wa-laysa 'alayh!” al-Shurūq, March 5, 2016, $<$ http://www.shorouknews.com/columns/view.aspx?cdate=05032016\&id=17e99bc9-7cb6-4d10 975b-fla59eabdfa6>.

İMĀN 'Alā’. "Hal kāna ‘ām 2016 “Ām al-Shabāb’ fílan?” Wikālat Sōlā Press, Dec. 27, 2916 , $<$ http://www.arabsolaa.com/articles/view/362631>.

"INNAHUM yaqra'ūna Walīd Dīdā." Akhbār al-Adab, February 14, 2016, p. 5.

"I Protect." Google Play Store, <https://play.google.com/store/apps/details?id=com.asker.zumoapp>, accessed April 13, 2018.

"I'RAF ārā' al-miṣriyyīn wa-iğābatahum 'alà as'ilatik." Nis'alak, <http://www.nes2alak.com>, accessed April 13, 2018.

ISLĀM Ğāwīsh. "Wa'llāhi wa-lā vīdēō wa-lā șūra wa-lā rasma bit-hizz illā al-ḍacîff al-cāğiz." Facebook, May 11, 2016, <https://fb.com/photo.php?fbid=1024323607636148>.

“KETĀPĒDIYĀ.” Facebook page, <https://www.facebook.com/ketapedia>, accessed April 13, 2018.

MAGED Atef. "Egypt's Police are Raiding Homes to Check Random People's Facebook Accounts." BuzzFeedNews, January 20, 2016, <https://www.buzzfeed.com/magedatef/egyptian-police-areperforming-random-facebook-checks-ahead?utm_term=.bm2BxBx1d\#.uveWmWmJD>.

Malm, Sara. "Puppet is Charged with Defying 'the Values and Ethics of Egypt' after Posing with a Copy of Fifty Shades of Grey in Satirical TV Show." MailOnline, April 25, 2016, <http:/ www.dailymail.co.uk/news/article-3557387/Puppet-charged-defying-values-ethics-Egypt-posingcopy-Fifty-Shades-Grey-satirical-TV-show.html>.

“"MAMNŪ' al-dukhūl'... 'An man' al-bāhithīn wa'l-akādēmiyȳ̄n al-ağānib min ziyārat Mișr.” Mu'assasat Hurriyyat al-Fikr wa'l-Ta'bir, February 8, 2016, <http://afteegypt.org/publications org/2016/02/07/11719-afteegypt.html>.

MAYY Muḥammad. "Ḥabs shurțiyya bi-mabāḥith al-ādāb li'ttihāmihā bi-hatk 'irụ 'āṭil fì 'Awsīm'." alBawwāba, April 7, 2016, <http://www.albawabhnews.com/1869862>.

MOHAMED. "ECRF Launches App to Counter Enforced Disappearances in Egypt." Egyptian Coordination for Rights and Freedoms, September 6, 2016, <http://ecrfeg.org/en/2016/09/06/ ecrflaunches-app-counter-enforced-disappearances-egypt>.

“"MushawwASH’ by Walīd Dīdā.” GoodReads, <https://www.goodreads.com/book/show/ 24492179>, accessed April 12, 2018.

MUMM. <https://www.getmumm.com>, accessed April 13, 2018.

MușṬAFÀ Māhir. "Sīb mōbāylak! 10 nașā’iḥ li-kull miṣrī kay lā ta taqilahu al-shurṭa 'indamā tufattish hātifahu." YallaFeed, May 9, 2016, <https://yallafeed.com/syb-mwbaylk-10-nsaeh-lkl-msry-ky-latatqlh-alshrth-andma-tft-sh-hatfh-4277>. 
NIRA Al Gammal, [comment on “Ēh? Afashtū lēh?”], Shady H. AbuZaid Facebook page, <https://fb. com/shady.h.abuzaid/posts/10156462830755402?comment id $=451851368355000>$, January 26, 2016.

OMAR Mohamed. “\#Hal_tatazawwaj_bint_ma'ahā_jawwāl.” Twitter, August 29, 2016, <https:// twitter.com/OoOmar_Mohamed/status/770129685942534144>.

"ORANGE and Vodafone Officially Launch 4G Services in Egypt." Egypt Independent, September 28, 2017, <http://www.egyptindependent.com/orange-vodafone-officially-launch-4g-services-egypt>.

"OrAnge Replaces Mobinil as Rebranding Hits Final Stages.” Digital Boom, Feb. 28, 2916, $<$ https://adigitalboom.com/orange-replaces-mobinil-as-rebranding-hits-final-stages>.

Pesha Magid. "The Syrian Kitchen: A Refugee Food Business Based on Quality not Empathy." Madà, August 31, 2016, <https:/www.madamasr.com/en/2016/08/31/feature/lifestyle/the-syrian-kitchena-refugee-food-business-based-on-quality-not-empathy>.

Petrillo, Marina. "Egypt's Protest Selfies: Campaign in Support of Detained Satirical Group." Reported.ly, May 13, 2016, <https://web.archive.org/web/20160514115358/https://reported.ly/ 2016/05/13/egypts-protest-selfies-campaign-in-support-of-detained-satirical-group>.

RADCLIFFE, Damian. Social Media in the Middle East: The Story of 2016, <https://damianradcliffe. files.wordpress.com/2016/12/social-media-in-the-middle-east-the-story-of-2016-final.pdf>.

"RAKnA: The Uber of Parking is Almost Here." CairoScene, February 23, 2016, <http://www. cairoscene.com/Geek/Rakna-The-Uber-of-Parking-Is-Almost-Here>.

RANIA. "il-Ra'̄is qāl ha-khlaq ğīl qādir 'alà al-hulm ha-khlaq min shabābhā nukhba ğidīda qādira 'alà al-taghyīr wa'l-tawğīh al-salīm wi-biyiḥ̦al.” Twitter, October 22, 2016, <https://twitter.com/ raniaahmed122/status/791257325369786369>.

"RAȘD lil-intihākāt allatī tușāhịib al-dhikrà al-khāmisa lil-thawra." Mu'assasat Hurriyyat al-Fikr wa'lTacbìr, n.d., <http://afteegypt.org/25-update>.

RASHAD, Jonathan: “Empty Tahrir.” Jadaliyya, February 1, 2016, <http://www.jadaliyya.com/Details/ 32936/Empty-Tahrir>.

"Rinam Saeed Sentenced to Prison for Airing Private Photographs of a Sexual Harassment Victim." Egyptian Streets, February 29, 2016, <https:/egyptianstreets.com/2016/02/29/riham-saeedsentenced-to-prison-for-airing-private-photographs-of-a-sexual-harassment-victim>.

SALmA Islam. "Pokemon Go Craze Sweeps Egypt as Concerns over Security Arise." Egyptian Streets, July 15, 2016, <https:/egyptianstreets.com/2016/07/15/pokemon-go-craze-sweeps-egypt-asconcerns-over-security-arise>.

SANĀ' 'Abd al-Wahhāb. “'Thawrat al-Internet' tuwāğih ziyādat kurūt al-maḥmūl: 'Mish ha-nishḥan'." September 16, 2016, <http://www.almasryalyoum.com/news/details/1009751>.

al-Ṣ̂Āī, Muḥammad. "Quwwāt al-amn tafḥaṣ hawātif al-muwāținīn... wa-tatașaffah 'al-Facebook'." al-Mūğaz, April 25, 2016, <https://web.archive.org/web/20160426152826/http://almogaz.com/ news/crime/2016/apr/25/2241123>.

al-SHABAKA al-'Arabiyya li-Ma'lūmāt Huqūq al-Insān / The Arabic Network for Human Rights Information. "Hunāka muttasa' lil-ğamīc ... Suğūn Miṣr qabla wa-ba'da thawrat Yanāyir." September 5, 2016, <http://anhri.net/هناك-متسع -للجميع>>

El SHImI, Rowan. "A Hopeful Year for Egypt's Cinema Industry.” Madà, December 28, 2016, $<$ https:/www.madamasr.com/en/2016/12/28/feature/culture/a-hopeful-year-for-egypts-cinemaindustry>.

SHURŪQ 'Abd al-'Aziz. "Ightișāb mu'āqa dhihniyyan fĩ Qism Shurțat Imbāba, lā yakhdish al-ḥiyā'." Shrouk Abdelaziz Facebook page, January 27, 2016, <https://fb.com/story.php?story_fbid= 534381940055819\&id $=444942555666425>$.

jais • 21 (2021) - Themed Section In2016: *187-*196 
“SISI: Don’t listen to anyone but me.” Madà, February 24, 2016, <https://www.madamasr.com/en/ 2016/02/24/news/u/sisi-dont-listen-to-anyone-but-me>.

“ṢUWAR: Mișrī yaltaqiẹ șuwar 'sēlfî’ mudhhila min a là al-amākin fî Mișr.” MBC Net, August 30, 2016,

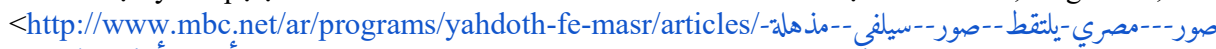
- من -أعلى-الأماكن -في-مصر/photos/214882.html>.

“TAȘĀ ¿ UD qalaq mu’ayyidī al-niẓām al-Mișrī min 'Jumhūriyyat Facebook'." al-Jazīra Mubāshir, March

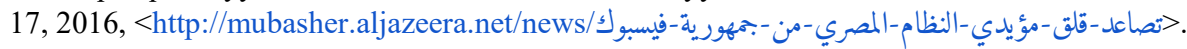

"The UbER of Food: Yumamia Turns Egyptian Housewives into Entrepreneurs." CairoScene, February 1, 2016, <http://www.cairoscene.com/Eats/The-Uber-of-Food-Yumamia-Turns-EgyptianHousewives-Into-Entrepreneurs>.

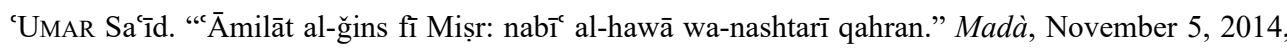
<https://www.madamasr.com/ar/2014/11/05/feature/lifestyle/_املات-الجنس-في-مصر-نبيع -الهوى" >

"VIRAL Facebook Post Stirs Controversy for Making the Case for Public Transportation in Egypt." CairoScene, December 4, 2016, <http:/www.cairoscene.com/Buzz/Viral-Facebook-Post-StirsControversy-for-Making-the-Case-for-Public-Transportation-in-Egypt>.

WĀ̉IL Thābit. "'Bașīra' li-buhūth al-ra’y al-'āmm yuṭliq taṭbīq 'Nis’allak' min Maktabat al-Iskandariyya." al-Bürșa, September 6, 2016, <https://www.alborsanews.com/2016/09/06/ 896004>.

WALsH, Declan. "Flamboyant Egyptian Politician Craves Public Eye." The New York Times, January 16, 2016, <https://www.nytimes.com/2016/01/17/world/middleeast/flamboyant-egyptianpolitician-craves-public-eye.html>.

YĀRĀ 'Imād. "Bi'l-ṣuwar - Tāmir Ḥusnī yattajih ilà Tūnis bi-ṣuḥbat Basma BūSīl.” Fī al-Fann, September 1, 2016, <http://www.filfan.com/news/details/56892>.

ZALAṬ, Shādī \& Muḥammad Hamāma. "“Ațfāl Shawāri"” bayna khawf al-dawla min al-sukhriyya... wa-khawfihā min al-shāric." Madà, May 11, 2016, <https://www.madamasr.com/ar/2016/05/11/ feature/ثقافة/أطفال-شوارع-بين-خوف-الدولة-من -السخرية>>

Movies

Hārr Ğäff Sayfan / Dry Hot Summers. Short film by Sharīf al-Bandārī. Egypt/Germany 2015.

Zahrat Halab / The Flower of Aleppo. Feature film by Rị̣à Bāhī. Tunisia 2016.

\albrecht.hofheinz@ikos.uio.no 